\title{
Nuclear waste policy falls victim to early general election
}

London

THE British government's abandonment of plans to build a shallow low-level nuclear waste dump at one of four rural sites has thrown its nuclear waste disposal policy into disarray and prompted accusations of electioneering. The investigations, by the Nuclear Industry Radioactive Waste Executive (NIREX), began last October in the face of fierce local opposition; all four sites were in the constituencies of Conservative members of parliament, and at the time the decision was made the general election date of 11 June - announced on Monday this week - already looked a certainty.

The decision was announced by the Secretary of State for the Environment, Nicholas Ridley, on 1 May, the day after he received revised costings from NIREX, indicating that it would be almost as economical to dispose of low- and intermediate-level waste together in the same deep underground repository. NIREX denies that its recommendation to stop the tests was influcnced by political considerations.

Ridley took the decision without consulting the government's own Radioactive Waste Management Advisory Committee, a group of independent experts who were closely involved with the choice of the sites and who had until last week been kept informed on the progress of the investigations. Members of the committee were angered by Ridley's failure even to give them prior notice of his decision, and

\section{Where to go now?}

London

Critics have raised reservations about the ability of the Drigg site to cope with the extra volume of low-level nuclear waste beyond 1990 (see above). BNFL says that a new system of compaction will allow Drigg to be used into the next century.

For a long-term solution to the problem, NIREX is now concentrating its efforts on the search for potential deep sites. Investigations began in October 1985, and three options have been identified, an inland underground mineshaft, and beneath the sea bed with access from either an on-shore tunnel or an off-shore platform.

The British Geological Survey has identified several areas, including remote islands, that are hydrogeologically sound. Planning, transport and radiological studies are being made, and several potential sites should be announced within 12 months. Site investigations would then take up to three years and, allowing for a public inquiry and construction, the repository would not be in operation before 2003, according to NIREX estimates. they regard his actions with scepticism.

Members of NIREX were themselves surprised at the speed with which Ridley approved and announced their recommendation, given that the investigations were due to be completed within days.

Initial estimates of the cost of shallow burial were around $£ 125$ per $\mathrm{m}^{3}$ but, according to NIREX, increased engineering safeguards, necessary to quell public anxiety, meant that the costs had risen to between $£ 500$ and $£ 1,100$ per $\mathrm{m}^{3}$; codumping with intermediate waste would provide a more publicly acceptable solution and would cost between $£ 750$ and $£ 1,200$ per $\mathrm{m}^{3}$ of low-level waste. The shallow repository would have come into operation in the early 1990s. Now, the $25,000 \mathrm{~m}^{3}$ of low-level waste produced each year will continue to be stored at the British Nuclear Fuels Ltd (BNFL) repository at Drigg, in Cumbria, and on site.

In recommending the abandonment of plans for a shallow dump, NIREX conceded that public acceptance of radioactive waste disposal is unlikely to be achieved in the short term.

Simon Hadlington

\section{Australia abandons nuclear energy}

Sydney

Australia's rejection of nuclear energy is complete with a change of name and direction for the Australian Atomic Energy Authority (AAEC). In its new guise as the Australian Nuclear Science and Technology Organization (ANSTO), it will no longer carry out research into uranium mining and enrichment or other aspects of the fuel cycle and power generation which were the basis of the AAEC's original charter. The only exception is SYNROC, its star project for nuclear waste disposal by immobilization in a ceramic.

The changes are intended to make the organization more responsive to the needs of industry. Besides basic research ANSTO will concentrate on the application of nuclear science to industry, medicine and the environment.

Australia came closest to adopting nuclear power in 1970 when plans were afoot to build a Canadian-designed power reactor $140 \mathrm{~km}$ south of Sydney. But plans were delayed as the anti-nuclear movement grew and large reserves of coal were discovered fairly near major cities. The project was shelved when a Labor government was elected in 1972, and no government has since revived it. Charles Morgan

\section{West Germany strides towards CFC elimination by 2000}

\section{Munich}

WEST Germany plans to push its chemical industry towards stricter controls on the production of chemicals that damage the ozone layer than those agreed at last week's meeting at Geneva of signatories of the Vienna convention. This emerges from the statement of an environmental official in Bonn on 4 May that the Geneva meeting did not go far enough towards eliminating emissions and production of chlorofluorocarbons (CFCs).

The West German Environment Office in West Berlin will soon begin talks with the chemical industry, asking for a neartotal elimination of CFC production and emissions by 2000 . The 31 states represented at Geneva in early May called for production cuts only of 50 per cent. This proposal will be put to an international conference in Montreal in September.

A government team of experts will begin a series of meetings with representatives of industry at the end of the month to discuss ways of reducing $\mathrm{CFC}$ production, starting with the aerosol industry. A member of the team, HansJürgen Nantke, says that the aerosol industry will be asked to reduce CFC production to 50 per cent of current levels within the next 18 months. If the industry refuses to comply, Nantke said, "we shall recommend that the Environment Minister issue regulations".

Surprisingly, the aerosol industry in West Germany is willing to abide by this request. Unlike CFC producers in Britain and France who strongly opposed the proposed reductions, German industry has already gone a long way towards elimination of all but 'essential' uses of CFCs. CFC production has been reduced from 53,000 tonnes in 1976 to 26,000 tonnes in 1986, with further reductions in sight. A spokesman for the aerosol industry attributed the fast pace of substitution of partially for fully halogenated compounds to presure from scientists.

Fully halogenated CFCs such as $\mathrm{CCl}_{13} \mathrm{~F}$ and $\mathrm{CCl}_{12} \mathrm{~F}_{2}$ are thought to contribute to the depletion of the stratospheric ozone layer. The effects of partially halogenated compounds such as $\mathrm{CHClF}_{2}$ are believed to be less. Aerosol cans may also be replaced by mechanical pumps. But the non-flammable qualities of the fully halogenated compounds make them essential for applications in the medical technology and electronics industries.

Steven Dickman 